Psycho-Analysis and Social Psychology

By Prof. William MeDougall. Pp. ix +207. (London : Methuen and Co., Ltd., 1936.) 7s. 6d. net.

Prof. McDougall says in his preface that he has "returned to the always interesting, but generally quite futile, task of criticizing the teachings of Professor Sigmund Freud and his school. . . . I have realized too late that $I$ might have done much more for my chosen science, had I from the first spoken with a less modest voice. It seems to me probable that, had I at the outset put forward my views in a more self-assertive and clamant fashion, I might have been acknowledged as the leader of a powerful and perhaps dominant school of psychology ; instead of remaining a well-nigh solitary outsider playing a lone hand".

Such a personal note, in the preface and even more in the three Lectures (delivered in the University of London, May 1935) which form the nucleus of the book, rather impedes the author in a critical handling of his subject. He holds that Freud is right in regarding human nature and behaviour as always and everywhere purposive, conative, hormic, but that in almost everything else Freud is in confusion or in error. On several points, the author makes pertinent criticisms, particularly in respect to the 'deathinstinct' about which Freud himself writes with scepticism, though nothing constructive is offered in their place. But the concepts of unconscious mental processes which affect not only neurotics but also normal people; of the persistence of infantile modes of thinking in this unconscious part of the mind; of an interplay between loving or tender and ag. gressive or destructive impulses which only slowly reach stability; the important part played by anxiety and guilt in the development of the personality, particularly in infancy-these and other characteristically Freudian concepts are either profoundly misinterpreted in the author's exposition, or ignored.

An understanding of social psychology is an urgent need at the present time, for never has propaganda been so rapid and intense as in Europe to-day. It is a matter for great regret that the opportunity offered to a pioneer in social psychology by a university and by publication should have been spent in a "futile task" rather than in developing the present state of knowledge by addition to theory or by new observation. JoHN RICKMAN.

\section{Aural Therapy in Relation to Deafness}

By Prof. D. F. Fraser-Harris. Pp. 45. (London: The Sterling Medical Publishing Co., n.d.) 7s. $6 d$. ThIs little book, which is introduced by forewords from Sir James Purves-Stewart and an anonymous professor of the faculty of medicine in an English university, consists of six chapters. In the first, in which a short account is given of the varieties of deafness, the author points out that deafness is very rarely the result of a direct infection of the central organ of hearing but is nearly always the secondary result of generalized infections, such as measles, scarlet fever, typhoid fever, rheumatism and some forms of catarrh of the nose and throat.
In the second chapter the various causes of deafness are described, such as obstruction in the external ear by a polypus or wax, perforation of the tympanic membrane and otosclerosis. In the third chapter, which is devoted to the diagnosis of deafness, a description is given of the audiograph, an instrument designed for the accurate measurement of sound. The result of its use has been that with certain exceptions the various types of deafness have been found to present characteristic audiographic charts of their own, which are reproduced. The remaining chapters are concerned with treatment, especially by hearing aids and the thermal catheter.

In conclusion, the author acknowledges the indebtedness of otology to the physicists who, from the time of Graham Bell, by their intensive study of the measurement of sound, have rendered possible the delicate acoustical instruments which have so advanced otology.

\section{Biological Time}

By Lecomte du Noüy. Pp. $x+180$. (London : Methuen and Co., Ltd., 1936.) 7s. 6d. net.

That the biological aspects of the conception of time form a real problem cannot be doubted. Even the expression 'biological time' may have a meaning, if judiciously defined. The present book is built around three experimental facts closely connected with the flow of time : (1) the very regular falling off in the rate of healing (the cicatrization index) of wounds according to the age of the organism; (2) the regular fall in the growth-promoting power of serum for explanted cells with the age of the donor; and (3) the dependence of the subjective estimation of time on experimentally alterable factors, especially temperature. The book, however, has many disadvantages. At least one third of it is not at all germane to the principal issue, and in many places we miss citations of the relevant literature, even where it is French, the language in which this book was first published. It is concluded, inter alia, that there is a physiological time which does not flow uniformly like physical time, and that time has a discontinuous or atomic nature. The book is un. fortunately marred by numerous errors of translation which in some cases may lead to confusion.

\section{Television Optics :}

an Introduction. By L. M. Myers. Pp. $\mathrm{x}+338$. (London: Sir Isaac Pitman and Sons, Ltd., 1936.) $30 s$, net.

In view of the many discursive books on the practice of television, this text is opportune, in that it sets out for the first time in book form the relevant physical data on lenses, Kerr cells, and electron focusing, and the relative effectiveness of various methods of scanning. More significant is its scientific accuracy and completeness; no important detail seems to be omitted which has a bearing on the optical performance of the many types of system. With its extensive bibliography and logical layout, Mr. Myers's book should prove to be a very valuable source of reference for students for many years to come. L. E. C. H. 